\title{
Large ungulates from the basal Oligocene of Oman: 3 - Anthracotheriidae
}

\section{Martin PICKFORD}

Sorbonne Universités - CR2P, MNHN, CNRS, UPMC - Paris VI, 8, rue Buffon, 75005, Paris, France; pickford@mnhn.fr

Pickford, M. 2015. Large ungulates from the basal Oligocene of Oman: 3 - Anthracotheriidae. [Grandes ungulados del Oligoceno basal de Oman: 3- Anthracotheriidae]. Spanish Journal of Palaeontology, 30 (2), 257-264.

\begin{abstract}
The presence of Anthracotheriidae, Artiodactyla, Mammalia, in the Early Oligocene of Oman was reported in 1992, but the fossils were never described. This paper rectifies the situation by describing two teeth that can be attributed to Bothriogenys gorringei, a species that is common in the Eocene-Oligocene Fayum deposits, Egypt. The Omani fossils help to fill a geographic gap that used to exist between the Fayum species on the one hand, and anthracothere species from the Far East on the other. The material consists of an upper molar from Thaytiniti and half a lower molar from Taqah.
\end{abstract}

Keywords: Anthracotheriidae, Oligocene, Oman, biogeography, Bothriogenys.

\section{RESUMEN}

La presencia de Anthracotheriidae, Artiodactyla, Mammalia, en el Oligoceno inferior de Omán fue registrada en 1992, aunque los fósiles nunca fueron descritos. Este trabajo suple esta limitación y se describen dos dientes que pueden ser atribuidos a Bothriogenys gorringei, una especie común en los depósitos del Eoceno-Oligoceno de Fayum (Egipto). Los fósiles de Omán permiten cubrir el vacío geográfico que existía entre las especies de Fayum y las especies de antracoceros de otras regions más orientales. El material estudiado consiste en un molar superior de Thaytiniti y medio molar inferior de Taqah.

Palabras clave: Anthracotheriidae, Oligoceno, Oman, biogeografia, Bothriogenys. 


\section{INTRODUCTION}

The presence of anthracotheres (Mammalia, Artiodactyla) in the Palaeogene of the Arabian Peninsula was first reported by Thomas et al. (1992) but the material basis for this listing was never published. Since then anthracotheres have been reported from Saudi Arabia by Zalmout et al. (2012) in two stratigraphic levels near the coast of the Red Sea (Late Eocene Usfan Formation and Early Oligocene Shumaysi Formation).

Even though Omani anthracotheriid fossils are scarce, they are sufficiently important for biochronology and biogeography to merit detailed description (Fig. 1).

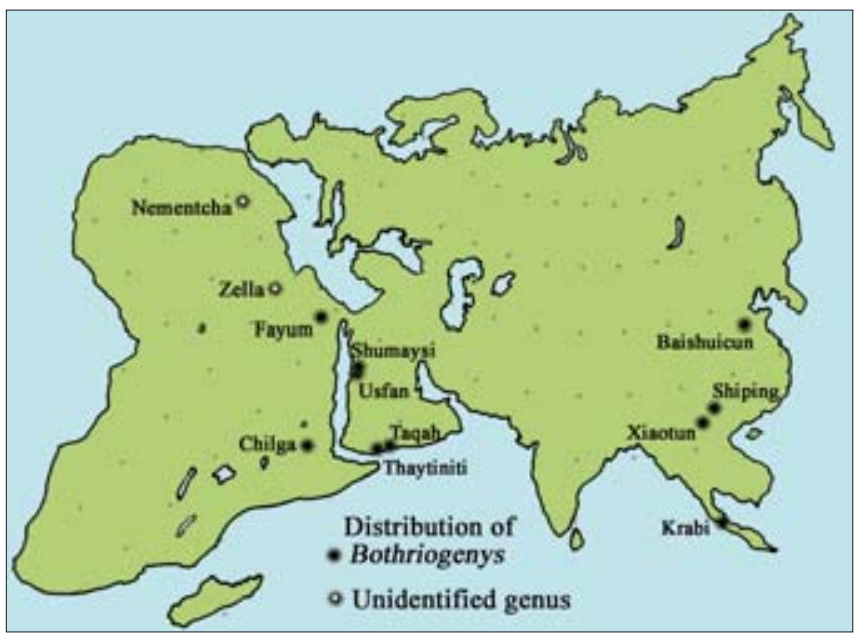

Figure 1. Distribution of the anthracotheriid genus Bothriogenys in Afro-Arabia and the Far East (after Ducrocq, 1997; Lihoreau \& Ducrocq, 2007; Holroyd et al., 2010; Tsubamoto et al., 2015; and this study). Note the strategic biogeographic position of the Omani fossils, which help to fill the gap that formerly separated the African and Far East samples. Also shown are two localities in Libya and Algeria from which fragmentary remains of anthracotheres have been reported (De Bonis et al., 1988; Rasmussen et al., 1992).

\section{MATERIAL AND METHODS}

There are two Palaeogene anthracotheriid specimens from Oman: ONHM TN 1992-4, a right M3/ from Thaytiniti: and ONHM TQ 1992-4, the distal half of a lower right molar (probably $\mathrm{m} / 2$ ) from Taqah.

Dental nomenclature is based on Lihoreau \& Ducrocq (2007) (Fig. 2). Specimens were measured with sliding calipers to the nearest $0.1 \mathrm{~mm}$. Images were captured with a Sony Cybershot 14.1 megapixel camera, and treated with Photoshop Elements 3 to remove background and to enhance the contrast. Scales were added manually.
The fossils are stored at the Natural History Museum, Muscat (ONHM). Comparisons were made with specimens housed in the Natural History Museum, London (NHMUK) and the Staatliches Museum für Naturkunde, Stuttgart (SMNS).

\section{SYSTEMATIC DESCRIPTION}

\author{
Order Artiodactyla Owen, 1848
}

Family Anthracotheriidae Leidy, 1869

Genus Bothriogenys Schmidt, 1913

Bothriogenys gorringei (Andrews \& Beadnell, 1902)

Diagnosis. See Lihoreau \& Ducrocq (2007) and Holroyd et al. (2010).

Description. The M3/ from Thaytiniti is almost unworn, but the paracone and parastyle are missing (Fig. 3). The tooth is pentacuspidate with a large mesostyle and metastyle. There is a prominent paraconule between the protocone and paracone. The paraconule is pyramidal with three faces. Its precrista extends mesio-buccally but terminates before the mesial cingulum. Its postcrista is directed almost directly distally. The preprotocrista reaches mesiolingually towards the anterior face of the paraconule. The postprotocrista is directed disto-centrally and ends in the median transverse valley at a low swelling, opposite a similar low swelling at the base of the prehypocrista. There is a third crest on the protocone descending towards the distal base of the paraconule. The postmetaconulecrista descends disto-centrally and ends before reaching the cingulum. The premetacrista curves mesio-buccally where it joins the postparacrista at a loop-like junction. From the buccal end of this junction, there is a fine crest directed disto-buccally towards the mesostyle which forms a large external cusplet. The metastyle is smaller than the mesostyle and is positioned on the buccal side of the tooth. The buccal surface of the metacone slopes strongly laterally. There is a prominent, sharp, serrated cingulum extending along the mesial and lingual surfaces of the tooth. The distal end of this cingulum climbs up slightly onto the metaconule. The distal cingulum is also serrated.

The $\mathrm{m} / 2$ (ONHM TQ 1992-4) is represented only by its distal half (Fig. 3). The hypoconid has three cristids, the precristid extending mesio-lingually well towards the lingual side of the crown. The middle cristid extends towards the entoconid and terminates opposite a cristid that runs mesiobuccally from the apex of the entoconid, thereby forming a v-shaped junction. The posthypocristid runs lingually reaching the rear of the entoconid, walling off the distal 


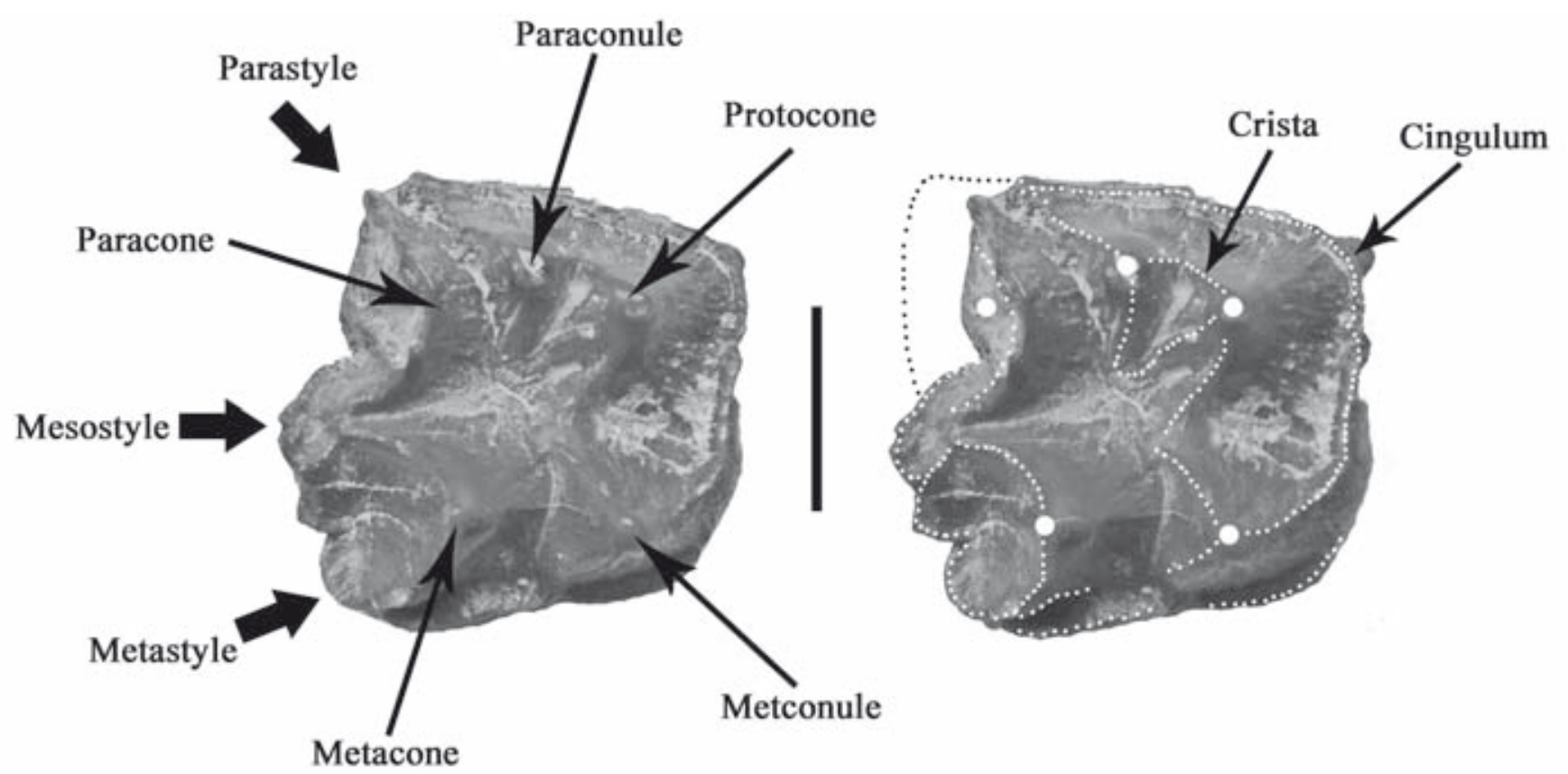

Figure 2. Dental nomenclature of a bothriodont upper molar, based on the terminology of Lihoreau \& Ducrocq (2007). Stereo occlusal view of ONHM TN 1992-4, right M3/. Scale: $10 \mathrm{~mm}$.

fovea. Behind this almost vertical wall is the distal cingulum. The entoconid has a cristid descending from its apex directly anteriorly. The buccal surface of the hypoconid is steep.

\section{DISCUSSION}

\subsection{Comparison}

The Thaytiniti M3/ is morphologically similar to a specimen of Bothriogenys fraasi curated in the NHMUK London (M 10186) (Fig. 4) but it is smaller, corresponding in dimensions to Bothriogenys gorringei (Table 1). The anthracotheriid M3/ from Thaytiniti is compatible in dimensions with two species from the Fayum, Bothriogenys gorringei and Bothriogenys rugulosus (Fig. 5). The more sloping buccal walls of the paracone and metacone indicate that the tooth belongs to Bothriogenys gorringei, those of B. rugulosus being more vertical (Ducrocq, 1997).

\subsection{Biogeography and palaeoecology}

Palaeogene anthracotheres have not previously been described from the Arabian Peninsula, but they have featured in faunal lists (Thomas et al., 1992) supplementary information of published papers (Zalmout et al., 2010) and abstracts (Zalmout et al., 2012). The genus Bothriogenys
Table 1. Measurements (in $\mathrm{mm}$ ) of the teeth of Bothriogenys gorringei from the Early Oligocene of Oman (TN Thaytiniti; TQ - Taqah) and B. fraasi from the Fayum, Egypt (NHMUK M 10186).

\begin{tabular}{lccc}
\hline \multicolumn{1}{c}{ Catalogue } & Tooth & $\begin{array}{c}\text { Mesio-distal } \\
\text { length }\end{array}$ & $\begin{array}{c}\text { Bucco-lingual } \\
\text { breadth }\end{array}$ \\
\hline ONHM TN 1992-4 & Right M3/ & 22.7 & 23.0 \\
ONHM TQ 1992-4 & $\begin{array}{c}\text { Right m/2 } \\
\text { distal half }\end{array}$ & -- & 13.4 \\
M 10186 & Right M3/ & 31.7 & 33.0 \\
\hline
\end{tabular}

is known from the Fayum, Egypt, the type locality, as well as from the Far East (Ducrocq, 1997; Tsubamoto et al., 2015). The Omani occurrence of this genus is thus of biogeographic interest as it helps to close the enormous geographic gap that formerly existed between the Egyptian and Asian species. The Omani fossils comprise two teeth which are close in dimensions and morphology to material of Bothriogenys gorringei, a species common in the Fayum deposits, Egypt (Schmidt, 1913; Ducrocq, 1997).

The presence of Bothriogenys gorringei at Thaytiniti and Taqah, Oman, underscores the similarity of the Omani faunas to those from the Fayum, Egypt (Thomas et al., 1999).

Apart from the Fayum occurrences, Palaeogene anthracotheres are rare in Africa, partly because of a paucity of deposits of this time span, but mainly because they were absent from the African continent until the end 

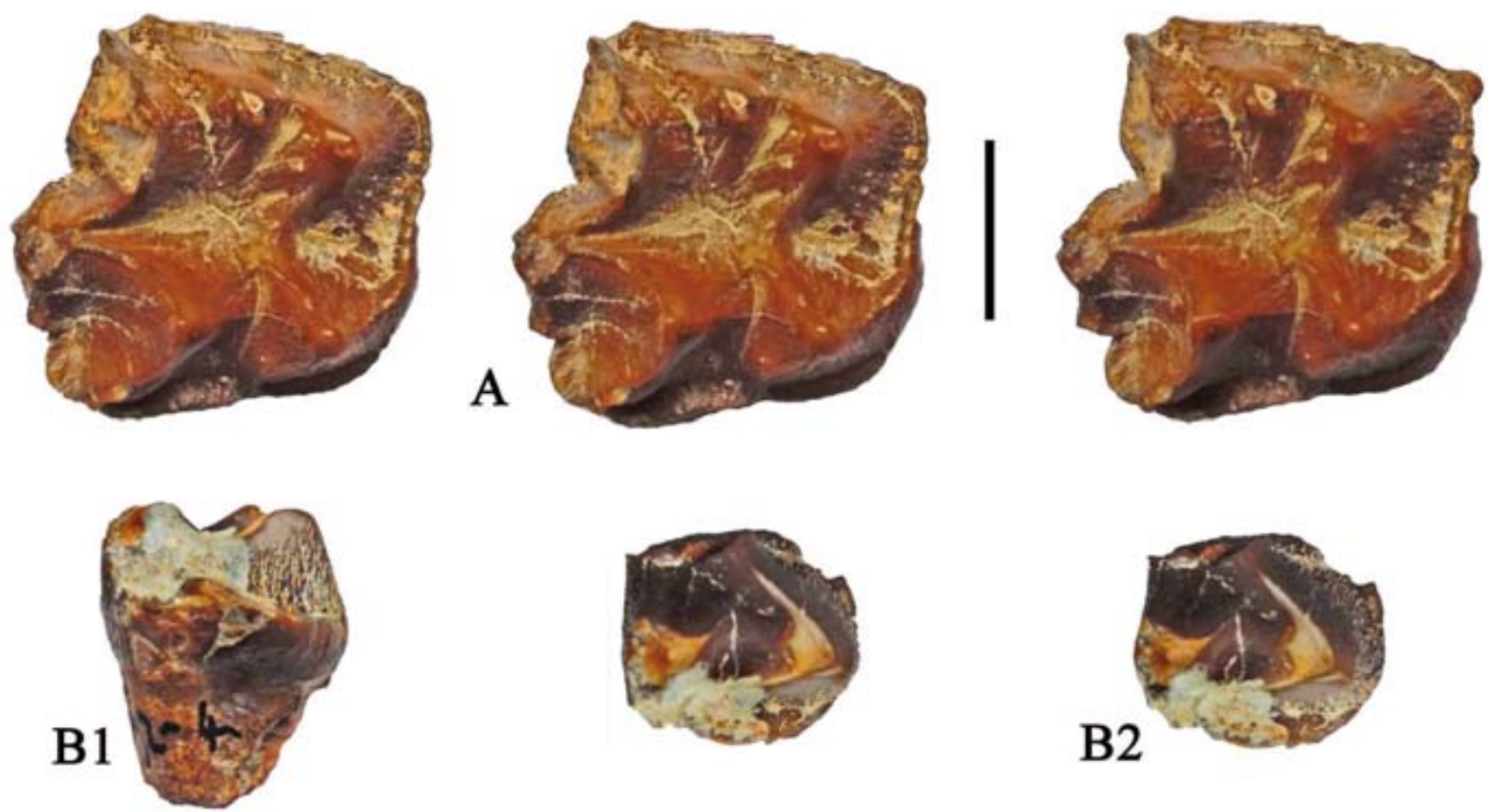

Figure 3. Anthracotheres from the Early Oligocene of Oman. A) ONHM TN 1992-4 right M3/ of Bothriogenys gorringei from Thaytiniti, stereo triplet of the occlusal view. B) ONHM TQ 1992-4 rear half of a right m/2, Bothriogenys gorringei from Taqah, (B1) distal view and (B2) stereo occlusal view. Scale: $10 \mathrm{~mm}$.

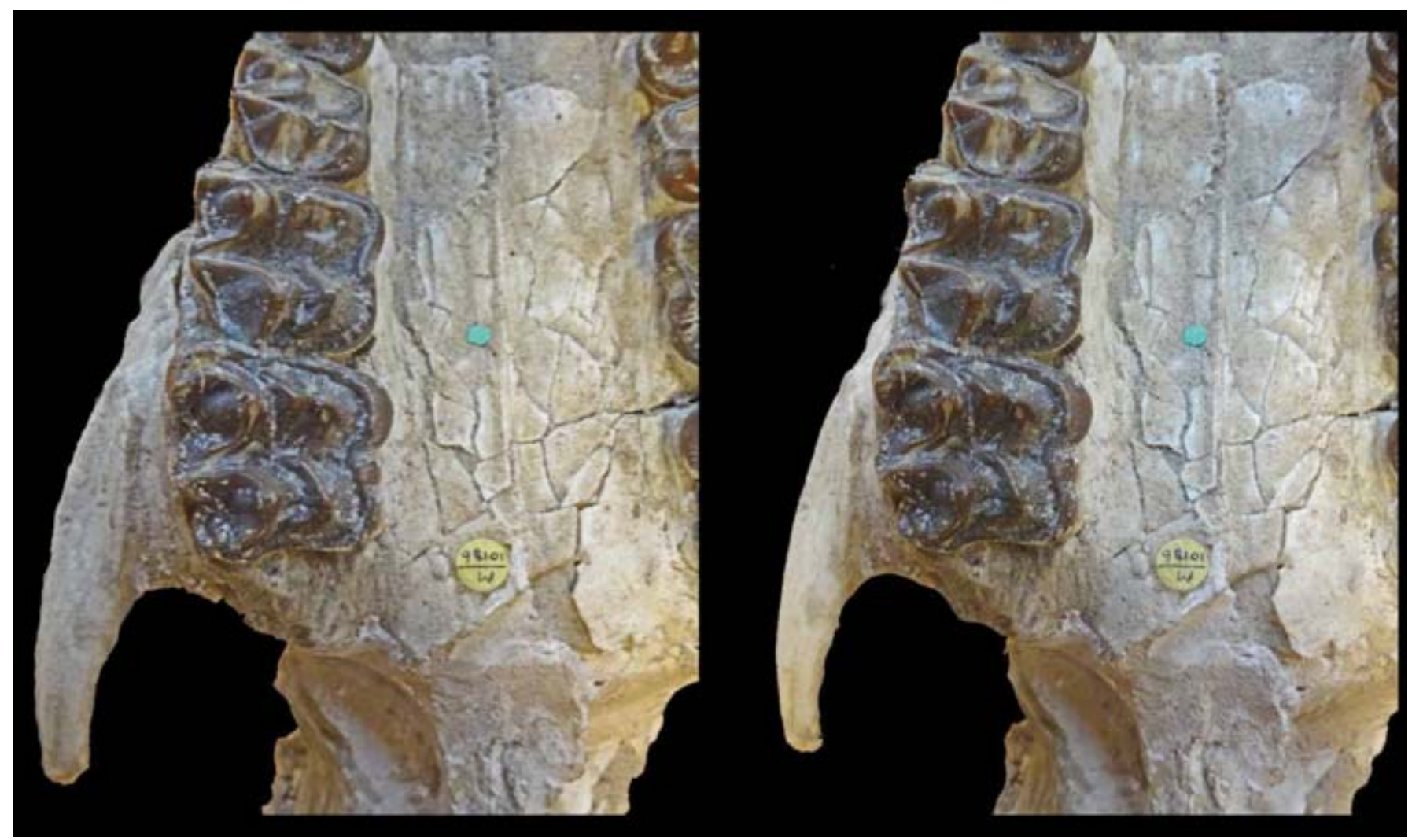

Figure 4. NHMUK M 10186, stereo view of upper right molars in a skull of Bothriogenys fraasi for comparison with the Thaytiniti specimen. Note the rudimentary metastyles in M1/ and M2/, contrasting with the extensive metastyle in M3/. 


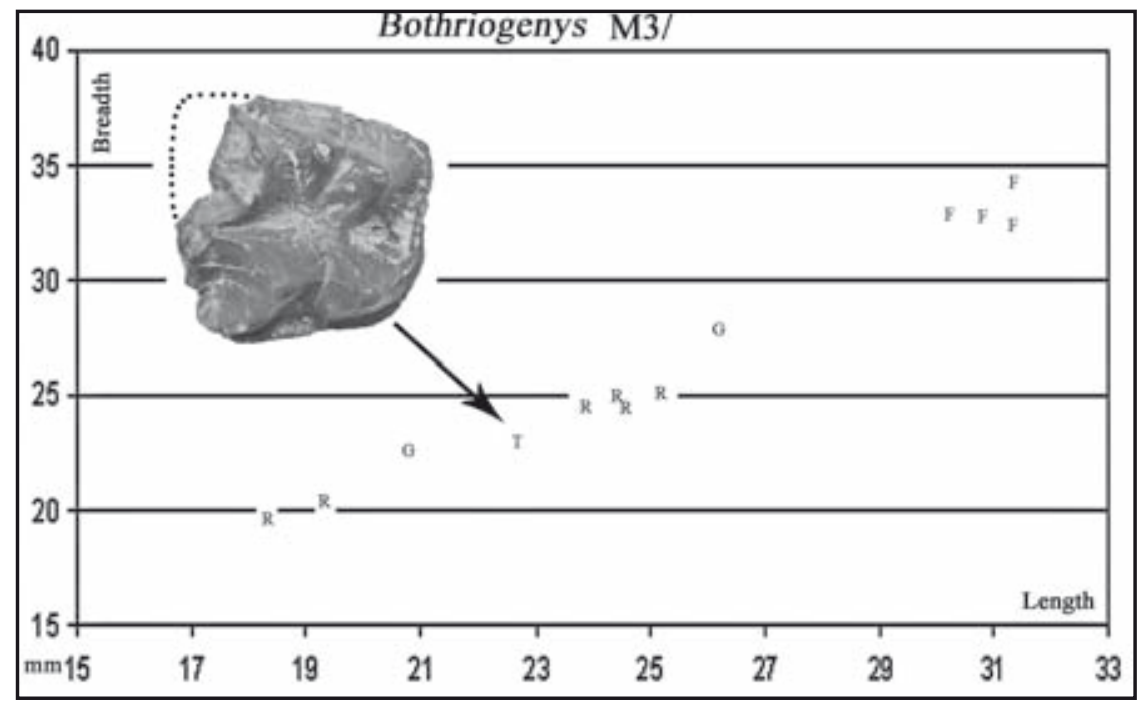

Figure 5. Metric comparison of the Thaytiniti upper third molar (T) with M3/s from the Fayum, Egypt, attributed to Bothriogenys gorringei $(\mathrm{G})$, Bothriogenys rugulosus (R) and Bothriogenys fraasi (F). Morphologically the Omani specimen is close to $B$. gorringe $i$ (data for the Fayum specimens is from Ducrocq, 1997). of the Eocene. The earliest known anthracothere (indeed the earliest known artiodactyl) from Africa is from the Qasr El-Sagha Formation in the Fayum (Andrews, 1906; Schmidt, 1913). The Usfan and Shuyamsi material, Saudi Arabia (Zalmout et al., 2012) is particularly important because it may well represent the initial wave of immigration into Afro-Arabia from Asia. One of the specimens has been attributed to Bothriogenys fraasi (Zalmout et al., 2010 supplementary figure $1 \mathrm{~m}$ ). The Thaytiniti record is somewhat younger than the earliest record in Egypt but is older than the recently described Epirigenys from the Oligocene of Lokone, Kenya (Lihoreau et al., 2015b).

Having colonised the continent at the end of the Eocene, anthracotheres persisted in Africa until the Late Miocene. They have been reported from the Late Oligocene strata of Chilga, Ethiopia (Kappelman et al., 2003) (referred to Bothriogenys by Lihoreau \& Ducrocq, 2007) and Losodok, Kenya (Rasmussen \& Gutierrez, 2009), from the Oligocene of Lokone, Kenya (Epirigenys lokonensis Lihoreau et al., 2015b) and are common in Early to Middle Miocene deposits in Northern, Equatorial and Southern Africa (Pickford, 1991a; Holroyd et al., 2010) the youngest records dating from Libya (Sahabi: Pavlakis \& Boaz, 2008), Chad (Agranga, Toros Menalla: Lihoreau et al., 2006, 2015a) and Uganda (Nyaburogo: Pickford, 1991b).

\subsection{Occupation of anthracothere niche by hippopotamids}

The demise of the Anthracotheriidae in Africa coincided with the rise of the Hippopotaminae (amphibious hippos sensu stricto, excluding the kenyapotamines and palaeopotamines which were more terrestrial in their habits) (Pickford, 2008), but it is still not clear whether the disappearance of anthracotheres in that continent was due to occupation of the amphibious niche by hippos, resulting in displacement followed by extinction, or whether the spread of hippos at the end of the Miocene only became possible because anthracotheres had already gone extinct there. Anthracotheres held on in the Indian Subcontinent and Southeast Asia until the late Pliocene (Lihoreau \& Ducrocq, 2007; Tsubamoto et al., 2012).

\subsection{Anthracothere-Hippopotamid relationships}

There is debate about the remote possibility that anthracotheres gave rise to hippopotamids (Lihoreau et al., 2015b) and thereby provide a phylogenetic link between Cetacea on the one hand and Hippopotamidae on the other, in line with molecular biological scenarios which link hippos to whales to the exclusion of other artiodactyls. However, this hypothesis leaves a vast chronological gap surpassing 30 million years between the supposed divergence date between whales and hippos (Eocene) and the earliest known hippos (Miocene). In the search for the mammal group that eliminates or reduces the excessive duration of this ghost lineage, some authors have consistently proposed that anthracotheres provide the link. The recent proposal that Epirigenys from the Oligocene of Lokone, Kenya, (Lihoreau et al., 2015b) fulfills this role, fails for the same reasons that previous proposals by the same team did. The first paper along these lines by the authors linked Late Miocene Libycosaurus to hippos and whales (Boisserie et al., 2005), a possibility that was refuted by Pickford (2008), the second essay linked hippos and whales via the Early Miocene genus Morotochoerus (Orliac et al., 2010) which was shown to be untenable by Pickford (2011), and the third linked Oligocene Epirigenys to hippos and whales (Lihoreau et al., 2015b). All these attempts to derive hippopotamids 
from anthracotheres fail because the authors did not take into account the post-cranial skeleton, and because they based their conclusions largely on dental remains which provided little support for their hypotheses, as explained by Pickford (2008, 2011). Lihoreau et al. (2015a) wrote that "Few postcranial bones have been attributed with certainty to anthracotheres. Fragmentary and eroded specimens appear very difficult to differentiate from the postcranials of hippopotamids that are equivalent in size, anatomically close and similarly display substantial morphological variations". This statement gives the erroneous impression that anthracothere and hippopotamid postcranial bones are similar to each other. However, Pickford (2008) showed that every bone in the skeletons of hippopotamids and anthracotheriids differ markedly from each other. Inclusion of the postcranial elements in the phylogenetic analyses invalidates the results based exclusively on dental and gnathic characters, much as it did with Delson's (1979) hypothesis that Oreopithecus, a hominoid primate, was a cercopithecid, on the basis of cladistic analysis of its dentition to the exclusion of its postcranial skeleton. In all these cases convergences in dental features were confused with phylogenetic signals.

\section{DISPERSAL OF ANTHRACOTHERIIDAE TO AFRICA AND PHYLOGENETIC SCENARIOS}

The Omani anthracotheriid fossils have another interest because anthracotheres were the first artiodactyls to disperse to Africa and because of this they have been interpreted by some authors (Lihoreau et al., 2015b) to represent the phylogenetic link between whales and hippos, a viewpoint which is challenged by other researchers (Pickford, 2008) who demonstrate the presence of substantial differences between the skeletons of hippos and anthracotheres, which renders it unlikely that the two groups are closely related.

\section{CONCLUSION}

Two anthracotheriid teeth from Early Oligocene deposits at Thaytiniti and Taqah, Oman, are identified as Bothriogenys gorringei. They were the first Palaeogene anthracotheres to be recorded from the Arabian Peninsula (Thomas et al., 1992) and even though the remains are limited, they are important for partly filling the enormous geographic gap of the range of the genus that formerly separated the Fayum, Egypt, species of the genus, from those that occur in China, Japan and Thailand in the Far East (Lihoreau
\& Ducrocq, 2007; Tsubamoto et al., 2015). The presence of this species in the Omani localities strengthens the affinities of the mammalian fauna to those from the Fayum, already noted by previous authors (Thomas et al., 1992). The Omani anthracotheriid teeth show no similarities to those of hippopotamids.

\section{ACKNOWLEDGEMENTS}

I thank Dr Tsubamoto for the review of the paper since the comments and suggestions have improved the quality of the first version of the manuscript. I thank the Oman Ministry of Commerce and Industry for research authorisation, and the Oman Natural History Museum (R. Al-Kindi) for access to fossils in its care. Thanks to the Natural History Museum, London (P. Brewer) and the Muséum National d'Histoire Naturelle, Paris (D. De Franceschi, C. Sagne) for allowing access to fossils in their care. The fossils were collected during expeditions to Oman led by H. Thomas in the early 1990's, funded by the Collège de France, the French BRGM and the CNRS. Funding for the 2013 and 2014 surveys by Sorbonne Universités - CR2P, MNHN, CNRS, UPMC - Paris VI, is gratefully acknowledged.

\section{REFERENCES}

Andrews, C.W. 1906. A Descriptive Catalogue of the Tertiary Vertebrata of the Fayum, Egypt. British Museum of Natural History, London.

Andrews, C.W. \& Beadnell, H.J.L. 1902. A preliminary note on some new mammals from the upper Eocene of Egypt. Egypt Survey Department, Public Works Ministry, Cairo, 1-9.

Boisserie, J.-R., Lihoreau, F. \& Brunet, M. 2005. The position of Hippopotamidae within Cetartiodactyla. Proceedings of the National Academy of Science, 102, 1537-1541.

De Bonis, L., Jaeger, J.-J., Coiffait, B. \& Coiffait, P. 1988. Découverte du plus ancien primate Catarrhinien connu dans l'Eocène supérieur d'Afrique du nord. Comptes Rendus de l'Académie des Sciences, Paris, 306, 929-934.

Delson, E. 1979. Oreopithecus is a cercopithecid after all. Abstracts American Journal of Physical Anthropology, 50, 431-432.

Ducrocq, S. 1997. The anthracotheriid genus Bothriogenys (Mammalia, Artiodactyla) in Africa and Asia during the Paleogene: phylogenetical and paleobiogeographical relationships. Stuttgarter Beiträge zur Naturkunde, B.250, 1-44.

Holroyd, P., Lihoreau, F., Gunnell, G. \& Miller, E. 2010. Anthracotheriidae. In: Cenozoic Mammals of Africa (eds. Werdelin, L. \& Sanders, W.). University of California Press, Berkeley, Los Angeles, London, 843-851.

Kappelman, J., Rasmussen, D.T., Sanders, W., Feseha, M., Bown, T., Copeland, P., Grabaugh, J., Fleagle, J., Glantz, 
M., Gordon, A., Jacobs, B., Maga, M., Muldoon, K., Pan, A., Pyne, L., Richmond, B., Ryan, T., Seiffert, E., Sen, S., Todd, L., Wiemann, M. \& Winkler, A. 2003. Oligocene mammals from Ethiopia and faunal exchange between Afro-Arabia and Eurasia. Nature, 2102, 1-4

Leidy, J. 1869. The extinct mammalian fauna of Dakota and Nebraska including an account of some allied forms from other localities, together with a synopsis of the mammalian remains of North America. Journal of the Academy of Sciences of Philadelphia, Series 2, 7, 1-472.

Lihoreau, F., Boisserie, J.-R., Blondel, C., Jacques, L., Likius, A., Makaye, H.T., Vignaud, P. \& Brunet, M. 2015a. Description and Paleobiology of a new species of Libycosaurus (Cetartiodactyla, Anthracotheriidae) from the Late Miocene of Toros-Menalla, northern Chad. Journal of Systematic Palaeontology, 12 (7), 761-798.

Lihoreau, F., Boisserie, J.-R., Manthi, F.K. \& Ducrocq, S. 2015b. Hippos stem from the longest sequence of terrestrial cetartiodactyl evolution in Africa. Nature Communications, 6, 6264, doi: 10.1038/ncomms7264

Lihoreau, F., Boisserie, J.-R., Viriot, L., Coppens, Y., Likius, A., Mackaye, H.T., Tafforeau, P., Vignaud, P. \& Brunet, M. 2006. Anthracothere dental anatomy reveals a late Miocene Chado-Libyan bioprovince. Proceedings of the National Academy of Sciences, 103, 8763-8767.

Lihoreau, F. \& Ducrocq, S. 2007. Family Anthracotheriidae: Systematics and Evolution. In: The Evolution of Artiodactyls (eds. Prothero, D. \& Foss, S.). Johns Hopkins University Press, Baltimore, 89-105.

Orliac, M.A., Boisserie, J.R., MacLatchy, L. \& Lihoreau, F. 2010. Early Miocene hippopotamids (Cetartiodactyla) constrain the phylogenetic and spatiotemporal settings of hippopotamid origin. Proceedings of the National Academy of Sciences, doi:10.1073/pnas.1001373107

Owen, R. 1848. Description of teeth and portions of jaw of two extinct anthracotherioid quadrupeds (Hyopotamus vectianus and Hyop. bovinus) discovered by the Marchioness of Hastings in the Eocene deposits of the N.W. coast of the Isle of Wight: with an attempt to develop Cuvier's idea of the classification of Pachyderms by the number of their toes. Quarterly Journal of the Geological Society of London, 4, 103-141.

Pavlakis, P. \& Boaz, N. 2008. Newly discovered remains of As Sahabi Anthracotheriidae. Garyounis Scientific Bulletin, Special Issue 5, 189-204.

Pickford, M. 1991a. Revision of the Neogene Anthracotheriidae of Africa. In: The Geology of Libya (ed. Salem, M. J.), Elsevier, Amsterdam, 4, 1491-1525.

Pickford, M. 1991b. Late Miocene anthracothere (Mammalia, Artiodactyla) from tropical Africa. Comptes Rendus de l'Académie des Sciences, Paris, 313, 709-715.
Pickford, M. 2008. The myth of the hippo-like anthracothere: The eternal problem of homology and convergence. Revista Española de Paleontología, 23, 31-90.

Pickford, M. 2011. Morotochoerus from Uganda (17.5 Ma) and Kenyapotamus from Kenya (13-11 Ma): implications for hippopotamid origins. Estudios geológicos, 67 (2), 523-540.

Rasmussen, D., Bown, T. \& Simons, E. 1992. The EoceneOligocene transition in continental Africa. In: EoceneOligocene Climatic and Biotic Evolution (eds. Prothero, D. \& Berggren, W.). Princeton University Press, Princeton, NJ, 548-566.

Rasmussen, D.T. \& Gutiérrez, M. 2009. A mammalian fauna from the late Oligocene of northwestern Kenya. Palaeontographica, Abteilung A 288, 1-52.

Schmidt, M. 1913. Über Paarhufer der fluviomarinen schichten des Fajum. Odontographisches und osteologisches material. Geologische und Paläontologische Abhandlungen, NS. 11 (3), 153-264.

Thomas, H., Roger, J., Sen, S. \& Al-Sulaimani, Z. 1992. Early Oligocene vertebrates from Dhofar (Sultanate of Oman). Geology of the Arab World, Cairo University, Cairo, 283-293.

Thomas, H., Roger, J., Sen, S., Pickford, M., Gheerbrant, E., Al-Sulaimani, Z. \& Al-Busaidi, S. 1999. Oligocene and Miocene terrestrial vertebrates in the southern Arabian Peninsula (Sultanate of Oman) and their geodynamic and palaeogeographic settings. In: Fossil Vertebrates of Arabia (eds. Whybrow, P. \& Hill, A.). Yale University Press, New Haven, 430-442.

Tsubamoto, T., Koda, Y., Hasegawa, Y., Nabana, S. \& Tomida, Y. 2015. Paleogene mammals from the Iwaki Formation in Japan: their implications for the geologic age and paleobiogeography of this formation. Journal of Asian Earth Sciences, 108, 18-32.

Tsubamoto, T., Thaung-Htike, Zin-Maung-Maung-Thein, Egi, N., Nishioka, Y., Maung-Maung \& Takai, M. 2012. New data on the Neogene anthracotheres (Mammalia; Artiodactyla) from central Myanmar. Journal of Vertebrate Paleontology, 32, 956-964.

Zalmout, I.S., Sanders, W.J., MacLatchy, L., Gunnell, G., Al-Muffareh, Y.A., Ali, M.A., Nasser, A.-A.H., Al-Masari, A.M. \& Al-Sobhi, S.A. 2010. New Oligocene primate from Saudi Arabia and the divergence of the apes and Old World monkeys. Nature, 466 (7304), 360-364, doi: 10.1038/nature09094

Zalmout, I.S., Gunnell, G., Almufarreh, Y., Ali, M., Nasser, A., Matari, A., Jamalaldeen, A. \& Gingerich, P. 2012. Oligocene Anthracotheriidae (Artiodactyla) from the Usfan and Shumaysi Formations, Western Saudi Arabia. Geological Society of America Abstracts with Programs, 44 (7), p. 605. 
